\title{
YURIDICAL ANALYSIS TO THE CONCEPT OF EXCLUSIVE ECONOMIC ZONES AND CONTINENTAL SHELF RELATING TO THE ISLAND OF SENKAKU / DIAOYU BETWEEN JAPAN AND CHINA BASED ON THE UNITED NATIONS CONVENTION ON THE LAW OF THE SEA 1982
}

\author{
Aldo Rico Geraldi \\ Faculty of Law and Social Sciences Ganesha University of Education \\ Email: aldoricogeraldi91@gmail.com
}

\begin{abstract}
This study aims to analyze the concept of an archipelagic state associated with the 1982 Sea Law Convention. In addition, this study also analyzes the dispute resolution of the exclusive economic zone and the continental shelf over the Senkaku / Diaoyu Islands claim between Japan and China.

This research uses normative legal research by examining a rule, principles, and legal doctrines related to the problems in this research to generate an argumentation. The data were collected by using literature study method by collecting legal materials and information in the form of primary, secondary, and tertiary legal materials. In order to obtain clear exposure, the data is then arranged systematically and analyzed using descriptive method.

The results of this study indicate that the archipelagic country is a country whose entire territory consists of one or more islands, including other interconnected islands, including waters among others and other natural forms. Furthermore, regarding the dispute of the Senkaku / Diaoyu archipelago, Japan can make measurements related to ZEE whose distance should not exceed 200 nautical miles measured from the same baseline and used to measure the width of its territorial sea. While related to China for the territorial sea width can reach a distance of 200 nautical miles from the base line used to set the width of its territorial sea, if the outer edge of the continental edge does not reach that distance.
\end{abstract}

Keywords: Archipelagic State, Exclusive Economic Zones, Continental Shelf, Senkaku/Diaoyu

\section{ABSTRAK}

Penelitian ini bertujuan untuk menganalisis konsep negara kepulauan terkait dengan Konvensi Hukum Laut 1982. Selain itu, penelitian ini juga menganalisis penyelesaian sengketa pengukuran zona ekonomi eksklusif dan landas kontinen atas klaim kepulauan Senkaku/Diaoyu antara Jepang dan Tiongkok.

Penelitian ini menggunakan penelitian hukum normatif dengan mengkaji suatu aturan-aturan, prinsip-prinsip, dan doktrin-doktrin hukum yang terkait 
dengan permasalahan dalam penelitian ini untuk menghasilkan suatu argumentasi. Pengumpulan data dilakukan dengan menggunakan metode studi kepustakaan dengan mengumpulkan bahan hukum dan informasi yang berupa bahan-bahan hukum primer, sekunder, maupun tersier. Dalam rangka mendapatkan pemaparan yang jelas, data tersebut kemudian disusun secara sistematis dan dianalisis dengan menggunakan metode deskriptif.

Hasil penelitian ini menunjukkan bahwa negara kepulauan merupakan negara yang seluruh wilayahnya terdiri dari satu atau lebih kepulauan, termasuk pulau-pulau lainnya yang saling berhubungan, termasuk perairan diantaranya serta wujud alamiah lainnya. Selanjutnya, mengenai sengketa kepulaun Senkaku/Diaoyu, Jepang dapat melakukan pengukuran terkait dengan ZEE yang jaraknya tidak boleh melebihi 200 mil laut diukur dari garis pangkal yang sama dan digunakan untuk mengukur lebar laut teritorialnya. Sedangkan terkait dengan China untuk lebar laut teritorialnya dapat mencapai jarak 200 mil laut dari garis pangkal yang dipakai untuk menetapkan lebar laut teritorialnya, apabila pinggiran luar tepi kontinen tidak mencapai jarak tersebut.

\section{Kata Kunci: Negara Kepulauan, Zona Ekonomi Eksklusif, Landas Kontinen, Senkaku/Diaoyu}

\section{Preliminary}

The development of postWorld War II sea law is the demand of most countries that want to expand its power in the sea bordering the coast. Everywhere it can be seen that coastal states, whether driven by political, economic or defense and security factors, extend the width of the territorial sea and sometimes up to the high seas (Boer Mauna, 2011:378).

Since 1958 many island countries in the Karibian and Indian and Pacific Oceans have become independent. At the same time, there is an increasing pressure to seek a special regime for the mid-ocean of the archipelago to be part of the archipelagic country. These include economic (fish and inter-island surveillance), politics (promoting island unity), security, prevention of illegal smuggling and entry and monitoring of pollution. The request as an archipelagic country special regime was discussed in the 1958 United Nations Conference on the Law of the Sea (UNCLOS III) of the archipelago country group of Fiji, Indonesia, Mauritus and the Philippines and the results Contained in section IV of the Sea Law Convention (R.R. Churchill and A.V. Lowe, 1983:91-92). Important elements of the new regime contained in section IV of UNCLOS are; First, the straight line of the archipelago can be drawn to the outermost part of an island in the archipelago; Second, create a new 
legal concept that is about the waters of the Islands in waters naturally adjacent and accommodated as the interests of shipping in coastal countries (Ibid).

The 1958 Geneva Convention has produced territorial sea and additional lines (Brian Opeskin and Martin Tsamenyi, 2006:329). It also establishes five maritime zones such as inland waters, territorial sea, additional lines, continental shelf, and high seas (Maria Gavouneli, 2007:3). Since the inception of the common heritage of mankind in the United Nations General Assembly in 1968, the international law of the sea has undergone a process of change in the form of increasing state power over the sea up to 200 miles from its shores, increased riparian state authority or riparian state of ship traffic in the straits and Increasing state authority to take marine environmental protection measures (Mochtar Kusumaatmadja, 1986:XI). As part of an archipelagic country, the sea has been shown to have various functions such as food sources, trade highways, means of conquest, battlegrounds, separators and national unites, and so on (Hasyim Djalal, 1979:1).

The importance of territory to state sovereignty led to the emergence of several disputes (Aldo Rico Geraldi, 2017:4). The potential sources of inter-state disputes can be borders, natural resources, environmental damage, trafficking, and other (Huala Adolf, 2004:1). The territory of a country consisting of land, sea and air above it becomes an important matter in international law, because without such territory a state can't be regarded as the subject of international law (Mochtar Kusumaatmadja dan Etty R. Agoes, 2003:161).

One of the disputes over the seizure of an archipelago region is being experienced by Japan and China related to the ownership status of Senkaku / Diaoyu island. Senkaku / Diaoyu Islands has been disputed since the post-World War II era. The dispute had no war, but the disputed islands made the relationship between Japan and China unharmonious (Izzato Millati, 2009:12). Senkaku is an archipelago located $170 \mathrm{~km}$ from Taiwan, 330 $\mathrm{km}$ from China, $170 \mathrm{~km}$ from Ishigaki (Japan) and $410 \mathrm{~km}$ from Okinawa (Japan) in the East China Sea (Japan Ministry of Foreign Affairs, 2013:2). The archipelago consists of eight islands with a total area of $6.3 \mathrm{~km}^{2}$ consisting of three islands of the islands are barren rock and the other five are small islands. The eight islands are Uotsurijima, Kitakojima, Minamikojima, Cuba, Taisho, Okinokitaiwa, Okinominamiiwa, and Tobise (Zhongqi Pan, 2007:71).

The Senkaku Islands are a small island with no human inhabitants, but the Senkaku Islands have abundant natural resources of petroleum and natural gas. This is what causes Japan and China both 
insist on defending it (Tribunnews, 20 November 2012). Differences in the sea line in the East China Sea (East China Sea) between Japan and China have not yet reached a mutual agreement. While both ratified the United Nations Convention on the Law of the Sea (UNCLOS) 1982, they developed an unfinished selfunderstanding. Japan proposes the division of the midline region in its exclusive economic zone (200 miles from the baseline), while China refers to the natural continuation of its continental shelf (beyond 200 miles) (International Kompas, 24 September 2012).

\section{Problems}

Based on the background that has been described above, the author raised two issues that include:

1. How does the concept of an archipelagic country linked to the 1982 United Nations Convention on the Law of the Sea?

2. How does the dispute resolution resolve the exclusive economic zone and the continental shelf over the Senkaku / Diaoyu islands claim between Japan and China?

\section{Research Methods}

This research uses normative legal research by examining the rules, principles, and legal doctrines related to the problems in this research to produce an argumentation (Mukti Fajar dan Yulianto Achmad, 2010:34). The data were collected by using literature study method by collecting legal materials and information in the form of primary, secondary, and tertiary legal materials (Aldo Rico Geraldi, 2014:3). In order to obtain clear exposure, the data is then arranged systematically and analyzed using descriptive method.

\section{Discussion}

Archipelago State in the 1982 United Nations Convention on the Law of the Sea Djuanda Declaration

The State of Indonesia recorded a new milestone in the field of law of the sea and strengthened the sovereignty of the Unitary State of the Republic of Indonesia when on 13 December 1957 Prime Minister Djuanda Kartawidjaja issued a declaration concerning the State Waters territory of the Republic of Indonesia stating that (Mochtar Kusumaatmadja, 1986:186-187):

"The geography of Indonesia as an archipelago consisting of thousands of islands has its own distinctive features. For the territorial integrity and to protect the wealth of the Indonesian State all the islands and the sea in between shall be regarded as a unified whole. The determination of the territorial sea boundary as set 
forth in the Territoriale Zeen en Maritime Kringen Ordonnantie 1939 Article 1 paragraph (1) is no longer in accordance with the above considerations because of the lack of the territory of Indonesia in separate parts with its own territory (Article 1 Territoriale Zeen en Maritime Kringen Ordonnantie (TZMKO) 1939)."

Based on these considerations the Government declares that all the waters around, between, and which connect the islands that belong to the Indonesian state with no view of the land of the Indonesian state and thus a part of the interior or national territory under Indonesian absolute sovereignty (T May Rudy, 2002:9). The peaceful traffic in these inland waters for foreign ships is guaranteed to be safe and merely does not conflict with / interfere with the sovereignty and safety of the State of Indonesia. Determination of the territorial sea boundary which is 12 miles wide is measured from the lines connecting the outermost points on the islands of the State of Indonesia (Mochtar Kusumaatmadja, op.cit.:187-188.).

The announcement of the Indonesian Government, now known as the Djuanda Declaration, was prepared in order to attend the Conference on the Law of the Sea in Geneva in February 1958. The Indonesian Government's announcement that Indonesia as an archipelago country came under strong protest from the United States, Australia, Britain, the Netherlands and New Zealand, but received support from the Soviet Union (at that time), and the People's Republic of China, Philippines, Ecuador (Mochtar Kusumaatmadja, 1978:29).

The Government of Indonesia continues the policy because it involves the sovereignty of the state of the sea and the resources contained therein. The Declaration of Djuanda was reaffirmed in a formal juridical way with the enactment of Law Number 4 / Prp 1960 on Indonesian Waters. With the Law No.4 / Prp / Year 1960, the total area of Indonesian sea that was 2.027.087 km2 (land) became $5,193,250 \mathrm{~km} 2$, an addition of the national jurisdiction (sea) of 3,166,163 km2 (Ibid:34).

On the other hand, on the international level the international community through the United Nations continues its efforts to codify the law of the sea through international conferences, the 1958 Conference on the Law of the Sea (UNCLOS I) which resulted in 4 (four) Conventions, but the Conference failed to determine the territorial sea width and the conception of the archipelago state proposed by Indonesia, followed by the second Conference (UNCLOS II) which also failed to establish two important rules of territorial sea and island countries. 


\section{Concept of the Archipelagic State in the United Nations Convention on the Law of the Sea 1982}

The Conference on the Law of the Sea I in Geneva in 1958 and the 1960 Sea Law Conference of 1960 still considerably define the status of archipelagic waters as the territorial sea's wide status alone is unsuccessful, the UN continues to codification and unification of international the law of the sea primarily commencing in 1973 where in 1970s was the beginning of the awakening awareness of the international community for the importance of regulating and maintaining a global environment including the marine environment.

Prior to the 1973 Sea Law Conference process, the UN General Assembly on 17 December 1970 succeeded in making Resolution No. 2749 (XXV), the Declaration of Principles Governing Sea Beds and Floors of the Sea and Wetlands beyond the National Limits of Jurisdiction, and Resolution No. 2750 (XXV) of the same date shall decide to invite all States in the Sea of Law Conference III. Resolution No. 2749 concerning the Declaration of Principles on the Seabed, the Seabed, and the Land below it beyond the boundaries of National Jurisdiction (Dewan Kelautan Indonesia, 2008:16).

The 1970 Declaration of Principles is due to the Maltese Government's initiative through its delegation, Arvid Pardo, that the seabed and its richness in it that is outside the jurisdiction of a state must be in a status for the benefit of mankind, subject to the principle of common heritage of mankind (Ibid). Indonesian delegates who have attended the sessions of the UN Seabed Committee since 1970 as observers have focused on the issue of further development rather than the idea of the common heritage of mankind and the marine problems of the region and the straits as this is of general concern to all conference participants as reflecting the aspirations of developing countries (Mochtar Kusumaatmadja, op.cit.:48).

Thinking about the concept of an archipelagic state then developed ahead of the start of the Third Sea Law Convention, primarily produced by experts from the archipelagic countries themselves. For example, the Writer at the annual meeting of the Law of the Sea Institute held at the University of Rhode Island in 1972 , proposed the concept of the homeland as a solid basis for demonstrating a close unity between terrestrial and marine areas, and introduced the concept of archipelagic waters to waters Located next to the archipelagic straight line (Mochtar Kusumaatmadja dan Etty R. Agoes, op.cit:176).

Through good diplomatic cooperation between Indonesia and the Philippines, which followed with Fiji and Mauritius, at sessions of the 
United Nations Sea-bed Committee that preceded the Third Sea Law Convention, an article on the archipelago succeeded in the session, and then the articles of the archipelago becomes the content of the negotiations (Third United Nations Conference on the Law of the Sea, 1973-1982).

At the session of the United Nations Seabed Committee Draft Articles from these four countries received responses from other countries, such as Britain supported by other major maritime nations, while in the sessions of the Draft Conferences of the Articles of the four countries which have received Improvements among others on the right of peace, received responses from groups of countries of Bulgaria, East Germany and Poland (Third United Nations Conference on the Law of the Sea, 1973-1982).

In subsequent debates, the concept of the island nation received considerable support from various participating countries, but it was accompanied by the notion that the principle of freedom of sailing and aviation was maintained primarily in parts of the sea that would change its status to archipelagic waters. Another requirement as proposed in the British proposal is that there is a need to establish a provision on the withdrawal of the base line and the definition of the archipelagic state objectively, the manner of drawing its base line, and the legal status of the waters covered by the base line.
While freedom of shipping through archipelagic waters and the obligations of the archipelagic countries not to obstruct shipping is a requirement proposed by groups of countries Bulgaria, East Germany and Poland (Mochtar Kusumaatmadja dan Etty R. Agoes, op.cit.:177-179).

The Soviet Union (at the time) argued that negotiations on an archipelagic state should be in the form of a package deal. Recognition of the archipelagic state must be balanced with the guarantee of its implementation sailing through the shortest routes in the archipelago pioneer and through routes commonly used for international shipping (Ibid).

Some countries whose territory is close to the archipelagic country also share their opinions. For example, Thailand expects the interests of neighboring countries to receive attention, in particular the right to exploit natural resources in some parts of the open sea sea, as well as the right of peaceful travel in other parts of archipelagic waters other than in the archipelagic sea lanes (Third United Nations Conference on the Law of the Sea, 1973-1982). In addition, Malaysia requested that it be given $a$ guarantee to remain able to use the former sea portion of the open sea for possible communication between the two parts of its territory (Third United Nations 
Conference on the Law of the Sea, 1973-1982).

All the status of the maritime regimes was successfully established through a long process. Conference of the Law of the Sea III, which began in the first session at UN Headquarters in New York on 315 December 1973, and finally the 3rd Conference (UNCLOS III) succeeded in establishing a Convention now known as the United Nations Convention on the Law of the Sea 1982, signed by 119 States in Jamaica's Montego Bay on 10 December 1982 (Dewan Kelautan Indonesia, op.cit.:7-8).

The concept of an archipelagic state gained recognition by the inclusion of Chapter 4 on an archipelagic state into the 1982 Sea Law Convention, which passed the legal provisions on the definition of an archipelagic state, the legal status of archipelagic waters, the rights of the archipelago, the sea lane and the right of peace (Mochtar Kusumaatmadja dan Etty R. Agoes, op.cit.:178). The archipelagic country is a country whose whole territory consists of one or more islands, including other interconnected islands, including the waters of them as well as other natural forms, which have sovereignty in archipelagic waters ie waters located in the inner edge of the archipelago. The outermost point of the island and the outermost dry reefs of the island nation (Ibid:179).
Article 46 (a) of the United Nations Convention on the Law of the Sea 1982 states that "an archipelagic State" means a country consisting entirely of one or more islands and may include other islands. Whereas in letter (b) states that, "Islands" means a group of islands, including parts of the island, waters among them and other natural forms which are so closely related to each other so that the islands, waters and other natural forms constitute a unity Geographical, economic and political, or historically regarded as such (Malcom N. Shaw QC, 2013:555).

There are several notes that can be taken from the definition that, (1) The archipelagic state is not included in the land of a country that has no beaches such as Denmark (Faroes), Ecuador (Galapagos Island), Norway (Spitsbergen), and Portugal (Azores). (2) The definition of an archipelagic state also includes countries that are generally not leading countries such as Japan, New Zaeland and the United Kingdom (R.R. Churchill and A.V. Lowe, op.cit.:92).

\section{Archipelagic Baselines}

The 1982 United Nations Convention On The Law Of The Sea grants the islanders the right to withdraw the archipelago as stipulated in Article 47. The archipelagic baselines is drawn to connect the outermost point of the 
outer islands and corals in an archipelago (I Made Andi Arsana, 2007:16). All the mainland of the country concerned should be part of the archipelagic basin system (Ibid). To be able to meet the use of archipelagic baselines in accordance with the United Nations Convention on the Law of the Sea 1982, there are several conditions that must be met as set forth in Article 47 of the United Nations Convention on the Law of the Sea 1982 (Article 60 paragraph (1-9) United Nations Convention on the Law of the Sea 1982).

The archipelagic country can draw a straight line of the archipelago connecting the outermost points of the outermost islands including the main islands with the ratio of archipelagic states between the sea and the land is one in one and nine to one (1:1 and 9: 1) (Albert W. Koers, 1994:11). The length of the base line shall not exceed 100 nautical miles, except for $3 \%$ of the total baselines pervading each island may exceed that length to a maximum of 125 nautical miles (Article 47 paragraph (2) United Nations Convention on the Law of the Sea 1982). The drawing of this base line should not deviate too far from the general configuration of the archipelago (Heru Prijanto, 2007:16), and also should not be drawn to and from the low-tide elevations unless there is a permanent lighthouse or installation and the distance does not exceed the territorial sea width, which is 12 miles from the nearest island (Dikdik Mohamad Sodik, 2014:44).

The archipelagic country should not draw a base line that intersects the territorial sea, or an exclusive economic zone of another country (Article 47 paragraph (5) United Nations Convention on the Law of the Sea 1982), and requires the island nation to respect the legitimate rights and interests of its neighboring country (Article 47 paragraph (6) United Nations Convention on the Law of the Sea 1982). The provisions of Article 47 paragraph (5) and paragraph (6) are stipulated to reduce the impact of withdrawal of archipelagic baselines on the rights and interests of neighboring countries, especially so as not to cause closed access from the territorial sea of neighboring countries. Another impact for neighboring countries protected by the 1982 United Nations Convention on the Law of the Sea is against the possibility of ending maritime communication between two parts of the territory of a nearby neighboring country, or the abolition of other legitimate rights and other interests traditionally exercised by the state in the present seas of the archipelagic waters (Etty R. Agoes, 2004:447).

The determination of this baseline should be included in the country map with a list of geographic coordinates that clearly define the geodatic datum (Article 
47 paragraph (8) United Nations Convention on the Law of the Sea 1982). Maps should be made on a scale sufficient to ensure their position. Therefore, the island nation must announce the map or list of such coordinates and deposit its copy in the UN Secretary (Article 47 paragraph (9) United Nations Convention on the Law of the Sea 1982). Furthermore, the territorial sea width, additional zones, exclusive economic zones and continental shelf shall be measured from the baselines of the islands drawn in accordance with article 47 (R.R. Churchill dan A.V. Lowe, op.cit.:93).

Settlement of Exclusive Economic Zone and Continental Shelf Dispute over Claim of Senkaku / Diaoyu Islands between Japan and China Exclusive Economic Zone Measurement

The dispute between Senkaku / Diaoyu between Japan and China is related to the claims of each country. Japan proposes the division of the region based on the midline in its exclusive economic zone 200 miles from the baseline. Japan can make measurements related to ZEE as set forth in the 1982 Sea Law Convention. The exclusive economic zone (ZEE) is defined as a sea lane located outside and adjacent to its territory that is subject to a special legal regime (Article 55 United Nations Convention on the Law of the Sea 1982). The Sea Law Convention on 1982 provides that each coastal state reserves the right to assign ZEE a distance not exceeding 200 nautical miles measured from the same baseline and used to measure the width of its territorial sea (Article 57 United Nations Convention on the Law of the Sea 1982).

The width of the ZEE is the result of a collective agreement of the participating nations in the United Nations Law of the Sea from 1973 to 1982 . The base line used for the 200-mile measurement is the base line at which the territorial sea width is measured. The base line may be a normal base line, a straight line from end to end, or the base line of the archipelago to archipelagic countries. The territorial sea and ZEE are both measured from the base line, then the width of ZEE is 200-12 nautical miles, which is 188 nautical miles. This is because the sea-wide acre of 12 nautical miles from the Sudha base line is the territorial sea that is part of the coastal state and is subject to the sovereignty of the coastal state.

Exclusive economic zones are not part of the coastal state and therefore are not subject to the sovereignty of the coastal state. The coastal state has only sovereign rights and exclusive jurisdiction in ZEE. In ZEE, coastal states have sovereign rights for exploration, exploitation, conservation, and management of natural, biological and non-biological resources from waters on the seafloor and from the 
seabed and underlying land and in respect of other activities for purposes Exploration and exploitation of such economic zones, such as energy from water, currents, and wind (Didik Mohamad Sodik, 2014:82).

Different with the sovereignty of a coastal state over the territorial sea or an island nation over its archipelagic waters, the coastal state's power over the fish resources contained in the exclusive economic zone is defined as sovereign rights. Based on this sovereign rights regime, the coastal state has no sovereignty. In this case, the sovereign rights possessed by a coastal state in ZEE are residual (Ivan Shearer, 1986:333), as they apply only to the biological resources contained within the zone and do not cover the waters and airspace thereon (M. Damhari, 1987:17).

Exclusive Economic Zone has special legal status sui generis and sui juris (Ivan Shearer, 2004:69). The specificity of this maritime zone is characterized by the enactment of rights and obligations by the 1982 Sea Law Convention both to coastal states and other countries (R.R. Churchill and A.V. Lowe, op.cit.:166). The reflection of sovereign rights is the enactment of the coastal state jurisdiction over ZEE in the form of the manufacture and use of artificial islands, instantiations and buildings, marine scientific research, and the protection and preservation of the marine environment (Article 56 paragraph (1) United Nations Convention on the Law of the Sea 1982). In exercising its rights and obligations in ZEE, the coastal state respects the rights of other countries and acts in conformity with the provisions of the Convention (Article 56 paragraph (2) United Nations Convention on the Law of the Sea 1982).

Other international legal provisions apply to activities in ZEE provided the provisions of international law are in accordance with the rights and jurisdiction of the coastal state (Didik Mohamad Sodik, op.cit,:84). Implementation of rights and obligations of other countries in ZEE should consider the rights and obligations of coastal states and the laws and regulations set by the coastal state (Article 58 paragraph (3) United Nations Convention on the Law of the Sea 1982). The coastal state is authorized to regulate the types of activities that are allowed and prohibited in ZEE. Such arrangements need to be included in the provisions on the prohibition of access to intelligence data and military activities (Ibid).

Other authorities of the coastal state are related to the granting of exclusive rights to regulate the manufacture, licensing, operation and use of artificial islands, installations and buildings, the drafting of customs, fiscal, immigration and sanitary legislation 
(Article 60 paragraph (1) and (2) United Nations Convention on the Law of the Sea 1982). The coastal state can establish safety zones around artificial islands, instalions and buildings. The width of the safeguard zone should be established with respect to applicable international standards (Article 60 paragraph (4) United Nations Convention on the Law of the Sea 1982). Foreign ships are required to respect the safety zone and adhere to generally accepted international standards on shipping safety (Article 60 paragraph (6) United Nations Convention on the Law of the Sea 1982). The existence of artificial islands, instalansi, buildings, security zones around them should not cause interference to international shipping (Article 60 paragraph (7) United Nations Convention on the Law of the Sea 1982).

\section{Measurement of The Continental Shelf}

China refers to the natural continuation of its continental shelf which is beyond 200 miles for the claiming or dispute of the Senkaku / Diaoyu patent with the Japanese. China may refer to the rules contained in the 1982 Sea Law Convention relating to the continental shelf. The coastal continental shelf covers the seabed and subsoil from the sea-level beyond its territorial sea along the natural continuation of its terrain to the periphery of the continental edges or to a width of 200 nautical miles from the base line used to establish the width of the sea Territorial, if the outer edge of the continental edge does not reach that distance (Jawahir Thontowi dan Pranoto Iskandar, 2006:188).

If the continental shelf exceeds the 200 nautical mile limit, the maximum width of the continental shelf is 350 miles from the base line from which the territorial sea width is measured on condition that the outer limits of the continental shelf are laid down under the provisions contained in the Convention (I Wayan Parthiana, 2003:186). The outer boundary of the continental shelf can reach as far as 100 nautical miles from the depth line or isobath 2500 meters in the outer edge of the continental margin or continental margin spaced more than 200 nautical miles from the territorial sea basin or coincides / overlaps with the outer boundary of ZEE (Didi Mohamad Sodik, op.cit.:113).

The criteria used in establishing the outer shelf of the continental shelf more than 200 nautical miles refers to a provision based on the outermost fixed point where the thickness of sedimentary rocks is at least $1 \%$ of the distance between the point and the foot of the continental slope or foot of the Slope and outer boundary not exceeding 350 nautical miles from the territorial sea line or not exceeding 100 nautical miles from 
the depth of 2500 meters (Eka Djunarsjah, 2004:239-241).

States with opposite or contiguous beaches, their mutual continental shelf may determine the borders of their continental shelf by agreeing on the basis of international law as set out in Article 38 of the Statute of the International Court of Justice to achieve a just settlement (Article 83 paragraph (1) United Nations Convention on the Law of the Sea 1982). The burden of the obligation to the parties to arrive at a consent because both formal and substantial agreements are the result of an agreement between the parties (I Wayan Parthiana 2, 2014:181).

The right of the coastal state to the continental shelf is a sovereign rights or to explore its continental shelf and exploit its natural resources (Article 77 paragraph (1) United Nations Convention on the Law of the Sea 1982). If the coastal state does not explore its continental shelf and exploit its natural resources, no country can perform such activities without the express consent of the coastal state because the right is related to an exclusive sovereign right. An exclusive right is a right which is specifically and solely granted to the subject concerned only, while the other subject has no such right (Article 77 paragraph (2) United Nations Convention on the Law of the Sea 1982).
The coastal state on the continental shelf is independent of occupation or occupation, either effective occupation or occupation of merely intent and purpose or in the form of a declared proclamation (Article 77 paragraph (3) United Nations Convention on the Law of the Sea 1982). The coastal state's natural resources consist of mineral resources or other mineral resources and other non-living resources contained in the seabed and underneath, includes living organisms belonging to species or species that remain attached or immobile (Article 77 paragraph (4) United Nations Convention on the Law of the Sea 1982).

The coastal state has the right to install cables and pipelines on the continental shelf (Article 79 paragraph (1) United Nations Convention on the Law of the Sea 1982). In addition, coastal states are also entitled to issue regulations relating to the prevention, reduction, and control of environmental pollution sourced from submarine cables and pipelines irrespective of the owner, however, this right shall not prevent the installation and maintenance of cables and pipelines (Article 79 paragraph (2) United Nations Convention on the Law of the Sea 1982). The development of artificial islands, installations and buildings on the continental shelf is the same as the exclusive economic zone (Article 60 United Nations 
Convention on the Law of the Sea 1982).

The coastal state has sovereign rights exclusively on its continental shelf, in addition to certain other non-exclusive rights. Other certain rights are also owned by other countries on the continental shelf of a country. These rights are the right to install submarine cables and pipelines (I Wayan Parthiana 2, op.cit.:178.). As a continuation of the right to install cable and submarine pipelines, other countries have the right to care. The rights to do the maintenance should not be hampered or obstructed by the coastal state (Article 79 paragraph (2) United Nations Convention on the Law of the Sea 1982). However, regarding the direction of cabling or piping must be approved by the coastal state in question (Article 79 paragraph (3) United Nations Convention on the Law of the Sea 1982).

\section{Conclusion}

1. The concept of an island nation gained recognition by the inclusion of Chapter 4 about an archipelagic state into the 1982 Sea Law Convention, which passed the legal provisions on the definition of an archipelagic state, the legal status of archipelagic waters, the right of archipelagic sea lanes passage and the right of peace. Article 46 letter (a) states that an archipelagic country is a country whose entire territory consists of one or more islands, including other interconnected islands, including waters among others and other natural entities, having sovereignty in archipelagic waters ie waters located on the side In from the straight baselines of the archipelago connecting the outermost points of the islands and the outermost dry reefs of the island nation.

2. The dispute of the Senkaku / Diaoyu islands between Japan and China is related to the claims of each country. Japan may make measurements related to ZEE as set out in the 1982 Sea Law Convention. Article 57 of the 1982 Sea Law Convention provides that each coastal state has the right to assign ZEE a distance not exceeding 200 nautical miles measured from the same baseline and used to measure wide territorial sea. The base line may be a normal base line, a straight line from end to end, or the base line of the archipelago to archipelagic countries. While related to China can refer to the rules contained in the 1982 Sea Law Convention relating to the continental shelf. The coastal continental shelf includes the seabed and subsoil from the sea-level beyond its territorial sea along the natural continuation of its terrain to the periphery of the continental edge or to a width of 200 nautical 
miles from the base line used to establish the width of the sea territorial, if the outer edge of the continental edge does not reach that distance. If the continental shelf exceeds the 200 nautical mile limit, the maximum width of the continental shelf is 350 miles from the base line from which the territorial sea width is measured on condition that the outer limits of the continental shelf are laid down under the provisions contained in the convention.

\section{Suggestion}

1. The governments of Japan and China are expected to make measurements related to the exclusive economic zone and the continental shelf against Senkaku / Diaoyu island in accordance with the rules applicable in the 1982 Sea Law Convention.

2. The governments of Japan and China should be able to resolve disputes that have been long enough to cause bad relations between the two countries. The settlement of the dispute can be resolved peacefully or with alternative dispute resolution. In addition, the dispute can also be resolved through the International Court of Justice.

\section{Bibliography Book}

Adolf, Huala, 2004, Hukum Penyelesaian Sengketa Internasional, Sinar Grafika, Jakarta.

Arsana, I Made Andi, 2007. Batas Maritim Antaranegara, Sebuah Tinjauan Teknis dan Yuridis, Gadjah Mada University Press, Yogyakarta.

Churchill, R.R. dan A.V. Lowe, 1983, The Law of The Sea, Manchester University Press, USA.

Djalal, Hasyim, 1979, Perjuangan Indonesia Di Bidang Hukum Laut, Binacipta, Bandung.

Fajar, Mukti dan Yulianto Achmad, 2010, Dualisme Penelitian Hukum Normatif \& Empiris, Pustaka Pelajar, Yogyakarta.

Gavouneli, Maria, 2007, Functional Jurisdiction in the Law of the Sea, Martinus Nijhoff Publishers, Leiden.

Kusumaatmadja, Mochtar, 1986, Hukum Laut Internasional, Binacipta, Bandung.

Kusumaatmadja, Mochtar, 1978, Bunga Rampai Hukum Laut, Binacipta, Bandung.

Kusumaatmadja, Mochtar dan Etty R. Agoes, 2003, Pengantar Hukum Internasional, Alumni, Jakarta.

Koers, Albert W., 1994, Konvensi Perserikatan Bangsa-Bangsa tentang Hukum Laut. Suatu Ringkasan, Gadjah Mada University Press, Yogyakarta.

Mauna, Boer, 2011, Hukum Internasional Pengertian, 
Peranan dan Fungsi dalam Era Dinamika Global, P.T. Alumni, Bandung.

Opeskin, Brian and Martin Tsamenyi, 2006, The Law of The Sea, Oxford University Press, Britania Raya.

Prijanto, Heru, 2007, Hukum Laut Internasional, Bayumedia Publishing, Malang.

Parthiana, I Wayan, 2003, Pengantar Hukum Internasional, Mandar Maju, Bandung.

Parthiana, I Wayan, 2014, Hukum Laut Internasional Dan Hukum Laut Indonesia, Yrama Widya, Bandung

Rudy, T May, 2002, Hukum Internasional 2, Refika Aditama, Bandung.

Shaw, Malcom N. QC, 2013, "Hukum Internasional", Terjemahan M.N. Shaw, International Law (Cambridge University Press 2006), Nusa Media, Bandung. Shearer, Ivan, 2004, Ocean Management Challenges for the Law of the Sea in the First Decade of the 21st Century, Martinus Nijhoff Publisher, Leiden.

Sodik, Dikdik Mohamad, 2014 Hukum Laut Internasional, PT Refika Aditama, Bandung.

Thontowi, Jawahir dan Pranoto Iskandar, 2006, Hukum Internasional Kontemporer, Refika Aditama, Bandung.

Article and Journal

Agoes, Etty R., Praktik NegaraNegara Atas Konsepsi Negara
Kepulauan, Jurnal Hukum Internasional, Volume 1 No. 3 2004.

Dewan Kelautan Indonesia, Evaluasi Kebijakan Dalam Rangka Implementasi Konvensi Hukum Laut Unternasional (UNCLOS 1982) di Indonesia, Departemen Kelautan dan Perikanan Sekretariat Jendral Satuan Kerja Dewan Kelautan Indonesia, Tahun Anggaran 2008.

Djunarsjah, Eka, Survei Hidrogafi Untuk Penetapan Batas Landas Kontinen (Hydrographic Survey for the Limitation of the Continental Shelf), UNPAD Journal of International Law, Vol. 40, No. 32004.

Damhari, M., The Fisheries Regime of the Exclusive Economic Zone, Martinus Nijhoff Publisher, Leiden.

Geraldi,

Aldo Rico, "Pertanggungjawaban

Pemerintah India Terkait Tindakan Pelanggaran Kekebalan Dan Keistimewaan Yang Dilakukan Terhadap Perwakilan Diplomatik Amerika Serikat Ditinjau Dari Ketentuan Hukum Internasional", Jurnal Komunikasi Ilmu Hukum, ISSN : 2356-4164, Volume 3, Nomor 1, (Pebruari 2017). , Aldo Rico, "Penyelesaian Sengketa Kasus Investasi AMCO VS Indonesia Melalui 
ICSID”, Kertha Semaya, Vol. 02, No. 02, (Februari 2014).

Pan, Zhongqi, Sino-Japanese Dispute over the Diaoyu/Senkaku Islands: The Pending Controversy from the Chinese Perspective, Journal of Chinese Political Science, vol. 12 , no. 1 (2007).

Shearer, Ivan, Problems of Jurisdiction and Law Enforcement Against Delinquent Vassels, International Comparative Law Quarterly, Vol. 35, 1986.

\section{Research Result}

Millati, Izzato, China dan Jepang dalam Sengketa Teritorial Kepulauan Senkaku (1970 2006). Skripsi Jurusan Ilmu Hubungan Internasional, Fakultas Ilmu Sosial dan Ilmu Politik, Universitas Muhammadiyah Yogyakarta, 2009.

\section{Legal Instruments}

Konvensi Hukum Laut 1982 (United Nations Convention on the Law of the Sea 1982). The United Nations Convention on the Law of the Sea was opened for signature at Montego Bay, Jamaica, on 10 December 1982. It entered into force on 14 November 1994.

Territoriale Zeen en Maritime Kringen Ordonnantie (TZMKO) 1939.

\section{Internet}

Susilo, Richard, Ini Alasan Mengapa Jepang Lebih Berhak Atas
Pulau Senkaku, 20 November 2012, URL: http://www.tribunnews.com /internasional/2012/11/20/ ini-alasan-mengapa-jepanglebih-berhak-atas-pulausenkaku?page=all, diakses pada tanggal 9 Juli 2017.

Irewati, Awani, Senkaku, antara Jepang dan China, 24 September 2012, URL: http://internasional.kompas. com $/ \mathrm{read} / 2012 / 09 / 24 / 053$ 41379/senkaku.antara.jepan g.dan.china, diakses pada tanggal 9 Juli 2017.

Third United Nations Conference on the Law of the Sea, 19731982, Concluded at Montego Bay, Jamaica on 10 December 1982, Document:-, A/CONF.62/C.2/L.49, Fiji, Indonesia, Mauritius and Philippines: draft articles relating to archipelagic States, Extract from the Official Records of the Third United Nations Conference on the Law of the Sea, Volume III (Documents of the Conference, First and Second Sessions), URL:

http://legal.un.org/diplomati cconferences/lawofthesea1982/docs/vol_III/a_conf62_c-2_l-49.pdf, diakses pada tanggal 9 Juli 2017. 